\title{
ARQUEOLOGÍA, ARQUITECTURA Y ARTE EN CAQUU, PROVINCIA DE HUARAL, LIMA ${ }^{(*)}$ \\ ARCHEOLOGY, ARCHITECTURE AND ART IN CAQUI, PROVINCE OF HUARAL, LIMA JORGE ALVINO LOLI ${ }^{(* *)}$ Y MIGUEL GUZMÁN JUÁREZ ${ }^{(* * *)}$
}

Fecha de recepción: 03 de noviembre de 2016

Fecha de aprobación: 14 de diciembre de 2016

\section{RESUMEN}

El presente trabajo es una síntesis de las investigaciones realizadas en el valle bajo del río Chancay, enfocadas en reconocer, registrar y analizar las expresiones culturales materializadas en los edificios históricos existentes en las cercanías de Caqui, antigua casa hacienda del distrito de Aucallama en la provincia de Huaral, departamento de Lima. El interés está en contextualizar las obras estéticas incorporadas en la arquitectura, percibiéndolas con relación a su medio geográfico espacial, así como a los procesos sociales en los cuales se insertaron temporalmente, para así comprender su significado social. En este sentido, se exponen dos tipos de expresión de contextos diferentes: las representaciones murales de la sociedad Chancay en el antiguo Perú, y las pinturas murales asociadas al sistema de 'haciendas' de inicios de la República.

\section{PALABRAS CLAVE}

Grafiti, nicho, pintura mural, casa hacienda, neoclásico, Caqui

\section{ABSTRACT}

The present work is a synthesis of the investigations carried out in the lower valley of the Chancay river, focused on recognizing, recording and analyzing the cultural expressions materialized in the historical buildings existing in the vicinity of Caqui, former hacienda house of the district of Aucallama in the province of Huaral, department of Lima. The interest is in contextualizing the aesthetic works incorporated in architecture, perceiving them in relation to their spatial geographical environment, as well as the social processes in which they were inserted temporarily, in order to understand their social meaning. In this sense, two types of expression of different contexts are exposed: the mural representations of the Chancay society in ancient Peru, and the murals associated with the 'haciendas' system of the beginning of the Republic.

\section{KEYWORDS}

Grafiti, niche, mural painting, house hacienda, neoclassic, Caqui

(*) El presente artículo es parte de las investigaciones que han realizado los autores en el valle de Chancay sobre el patrimonio arqueológico, virreinal y republicano. En el caso del primer autor, esta investigación forma parte del curso "La República y el arte peruano en el siglo XIX", seguido en la Maestría de Arte Peruano (2016) de la Facultad de Letras y Ciencias Humanas, Universidad Nacional Mayor de San Marcos (UNMSM), Lima. Asimismo, corresponde parcialmente a la publicación del libro Arquitectura Chancay (2016) realizada por el segundo autor, como resultado de su tesis de maestría en Arqueología Andina (UNMSM, 2011). Finalmente, ambos autores dirigieron la participación de los alumnos del curso Conservación del Patrimonio Edificado de la Universidad Ricardo Palma (grupo 03 a cargo de Miguel Guzmán, ciclo 2016-1), para los levantamientos y propuestas respectivas de la hacienda Caqui. (**) Graduado de la Facultad de Arquitectura y Urbanismo de la Universidad Ricardo Palma (URP). Graduado de la Facultad de Ciencias Sociales en la especialidad de Arqueología de la Universidad Nacional Mayor de San Marcos (UNMSM). Estudios de Maestría en Conservación del Patrimonio Edificado en la Universidad Nacional de Ingeniería (UNI), Maestría en Museología y Gestión Cultural en URP, y Maestría en Historia del Arte Peruano en la UNMSM. Ha ejercido docencia en la UNMSM, Universidad Peruana de Arte Orval, y en Talleres de Capacitación Docente del Instituto Nuevos Tiempos. Contacto: jc alvino@hotmail.com

${ }^{(* * *)}$ Arquitecto por la Universidad Ricardo Palma. Magíster en Arqueología Andina por la UNMSM. Candidato a Doctor en Ciencias Sociales, mención en Antropología, por la misma universidad. Docente en la Facultades de Arquitectura de la Universidad Ricardo Palma, Universidad Peruana de Ciencias Aplicadas. Ha sido docente en la Escuela de Arqueología de la UNMSM, en la Maestría de Museología y Gestión Cultural Escuela de Posgrado URP. Miembro fundador del Instituto Arqueo-Arquitectura Andina (IAAA). Es docente investigador del Centro de Investigación de la Universidad Ricardo Palma. Ha participado en el equipo del Proyecto Arqueológico Pisquillo Las Shicras-Chancay $(2006,2013)$. Contacto: quillca@hotmail.com 
devenir Vol. 3, N6, JULIO-DICIEMBRE 2016, PP. 143-162 - EsTUDIOS I ISSN 2312-7570

UNIVERSIDAD NACIONAL DE INGENIERÍ, LIMA

Figura 1. Ubicación de Caqui en la margen izquierda del valle bajo del río Chancay. Aucallama y Palpa son de las primeras haciendas históricas que existieron en la costa central a inicios de la Colonia en el Perú.

Fuente: Elaboración propia, Jorge Alvino y Miguel Guzmán, sobre la Carta Nacional 24-i, 1971.

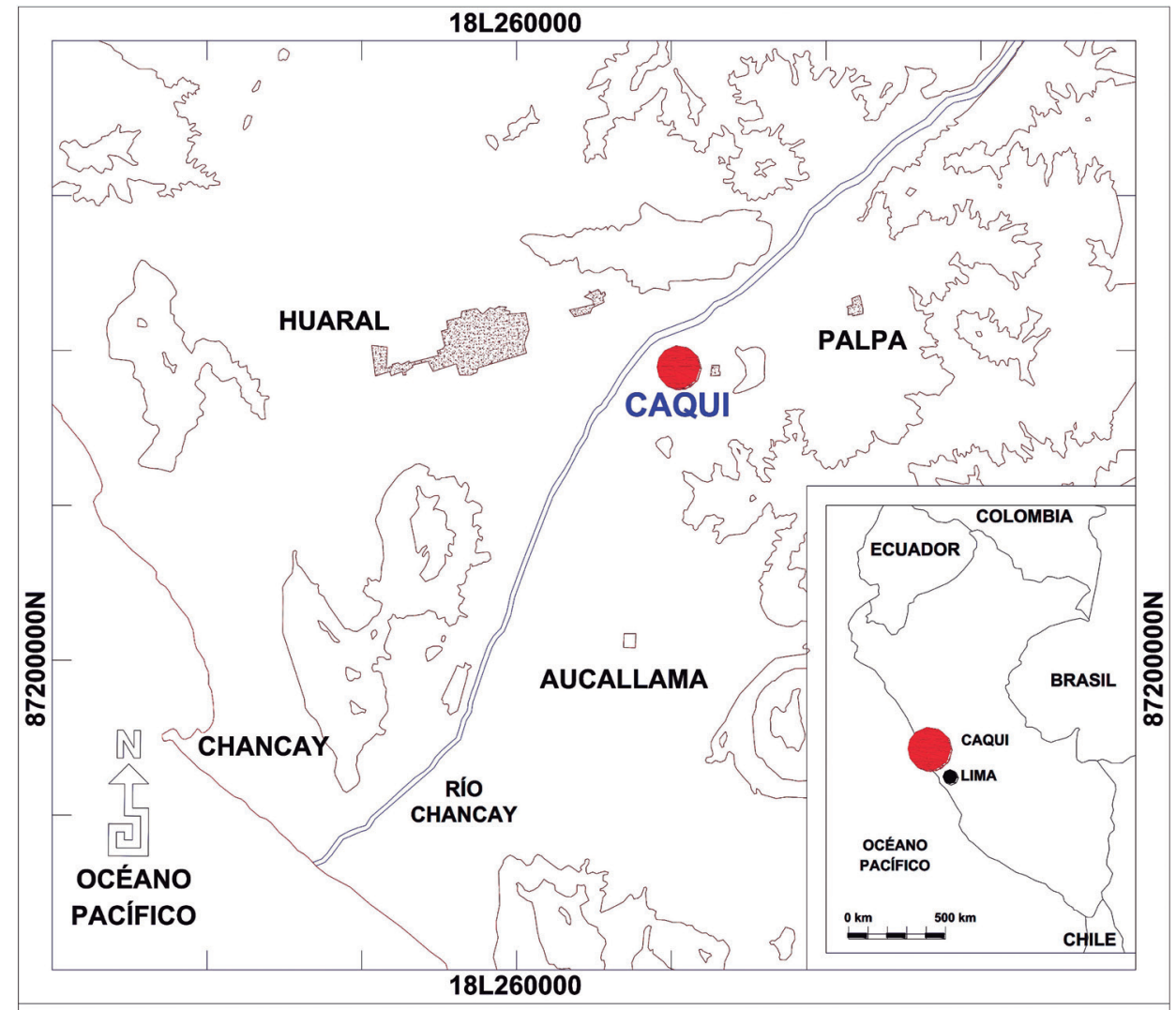

UBICACIÓN DE CAQUI EN EL PERÚ Y EN EL VALLE DE CHANCAY

El sistema geográfico andino contiene una multitud de estructuras espaciales naturales en las cuales el ser humano se ha establecido en diferentes momentos de su historia; estas estructuras espaciales muchas veces han servido como lugares y soportes en los cuales se ha podido materializar distintas imágenes realizadas por las sociedades a través del tiempo, modificándolas físicamente y otorgándoles un significado social diverso. Las representaciones de imágenes adquieren ciertas características que muchas veces no poseen otras, por lo cual su entendimiento implica métodos e implementos complementarios al registro histórico y arqueológico. Aun así, su análisis no implica un método ni un proceso único ni determinado, y la pérdida o fragmentación de su contexto espacial limita su cabal interpretación.

Para el análisis se ha empleado algunos métodos de campo, entre los cuales están los correspondientes al levantamiento planimétrico arquitectónico - tanto para el edificio 'prehispánico' como para la casa hacienda republicana-, así como el referente a la expresión artística a partir de fotografías y de la observación directa. Ambos edificios, tanto el arqueológico como la misma casa hacienda, se encuentran asentados sobre una formación de granito aflorante que destaca dentro de la llanura del valle, la cual es irrigada por diversos canales ubicados entre Palpa y Caqui (distrito de Aucallama).

Las primeras aproximaciones sobre estas imágenes 'prehispánicas' en el valle de Chancay (Figura 1) se dieron con los reportes y hallazgos de Hans Horkheimer (1965), quien las registró espacial y físicamente, además de su contexto inmediato y los sitios cercanos vinculados a dicha sociedad. Horkheimer analizó dos expresiones ubicadas dentro de un solo edificio, conocido como La Bandurria, el cual posee características singulares 
para el valle: i) grafitis figurativos impresos en muros y ii) nichos escalonados asociados a la influencia del Tawantinsuyu. En cuanto a las expresiones murales asociadas a la casa hacienda, estas se vinculan socialmente a la naciente República del Perú, a mediados del siglo XIX, y se agrupan en tres espacios al interior de la misma casa hacienda de Caqui: i) pinturas del patio y zaguán, ii) pinturas del atrio, y iii) pinturas de la capilla y sacristía.

\section{El edificio La Bandurria'}

La investigación arqueológica propone la existencia de la sociedad yunga, conocida como chancay, ubicada temporalmente entre los siglos VII y XVI d.C., distribuida entre los valles de Supe, Huaura, Chancay y Chillón, en la costa central andina. En el valle de Chancay se han identificado grandes asentamientos como Pisquillo Chico, Lumbra, Laure, Tronconal, Pancha la Huaca y Miraflores (estos dos últimos desaparecidos); destacan entre los edificios más singulares algunos existentes en Caqui, no solo por su tipología, sino también porque presentan algunos rasgos que podrían indicar la presencia del Tawantinsuyu en el valle.

Los distintos sectores arqueológicos de Caqui se encuentran cerca al actual poblado que lleva el mismo nombre, y se emplazan sobre un afloramiento geológico del cerro La Bóveda, que se eleva a más de 100 metros sobre el nivel de terreno cultivable. Existen otros afloramientos: dos pequeñas elevaciones en el extremo norte, que son conocidos como La Bandurria, en uno de los cuales se emplaza el edificio que se analizará. El conjunto se halla rodeado de grandes extensiones de terreno cultivable y alejado de las cadenas montañosas, por lo que adquiere prominencia desde esta sección del valle bajo, que es más bien el llano del delta de deyección. Otros puntos de referencia geográfica son la cúspide del cerro Bilbao hacia el Norte, el cerro Señal Pisquillo hacia el Este, el cono de deyección del río hacia el Oeste y a lo lejos el cerro más alto del valle, el Macatón.

El edificio La Bandurria se ubica exactamente en las coordenadas 18L 0225870 y UTM 8727920 N, a 270 m.s.n.m. Ocupa un tercio del cerro sobre el que está emplazado y cubre cerca de 4,000 $\mathrm{m}^{2}$. El edificio (de aproximadamente 60 metros de largo, 25 de ancho y 10 de alto) se construyó usando el sistema de tapias, y también cuenta con algunos sectores de adobe. Frente a su lado norte un extenso cerco escalonado que se adapta al relieve del cerro delimita una gran área abierta cuadrangular, y continúa por el frente oeste y luego por el sur, de forma que crea una envolvente rectangular que encierra a la plataforma principal. Este singular muro también está construido de tapiales y cuenta con grandes bloques de piedra en la parte inferior.

Horkheimer (1965) llama 'templete' a dicho edificio principal (Figuras 3 y 4). Su configuración en planta corresponde a una secuencia de tres grandes recintos rectangulares dispuestos uno después del otro en dirección del eje Este-Oeste. Además, está rodeado por un sistema de canales de circulación que bordea los recintos en dos direcciones, y forma pasajes cerrados cuando se dirige de Sur a Norte, y abiertos de un lado y hacia el exterior cuando se dirigen de Este a Oeste. Destaca sobre todo el pasaje central norte-sur, a partir del cual se pueden percibir dos sectores diferenciados (este y oeste), pues este actúa como elemento divisorio del edificio; incluso alineado con este se articula el posible acceso principal a todo el edificio, a través de una larga rampa flanqueada por gruesos parapetos desde el nivel llano del suelo natural (hoy este elemento de circulación vertical se encuentra cortado por una trocha actual). Desde la rampa de ingreso se accede inmediatamente al nivel superior de todo el edificio (cuya plataforma superior se eleva aproximadamente 6.00 metros) y se inicia un recorrido hacia la izquierda, que prosigue sobre el borde exterior de toda la plataforma hasta llegar a la esquina suroeste, donde existe un acceso al recinto oeste.

1. El registro de este edificio y de los grafitis, así como de otras manifestaciones culturales prehispánicas en Caqui, tales como petroglifos, han sido parte de investigaciones expuestas en conferencias (Alvino, 2009). 
devenir Vol. 3, N6, JULIO-DICIEMBRE 2016, PP. 143-162 - EsTUDIOS I ISSN 2312-7570
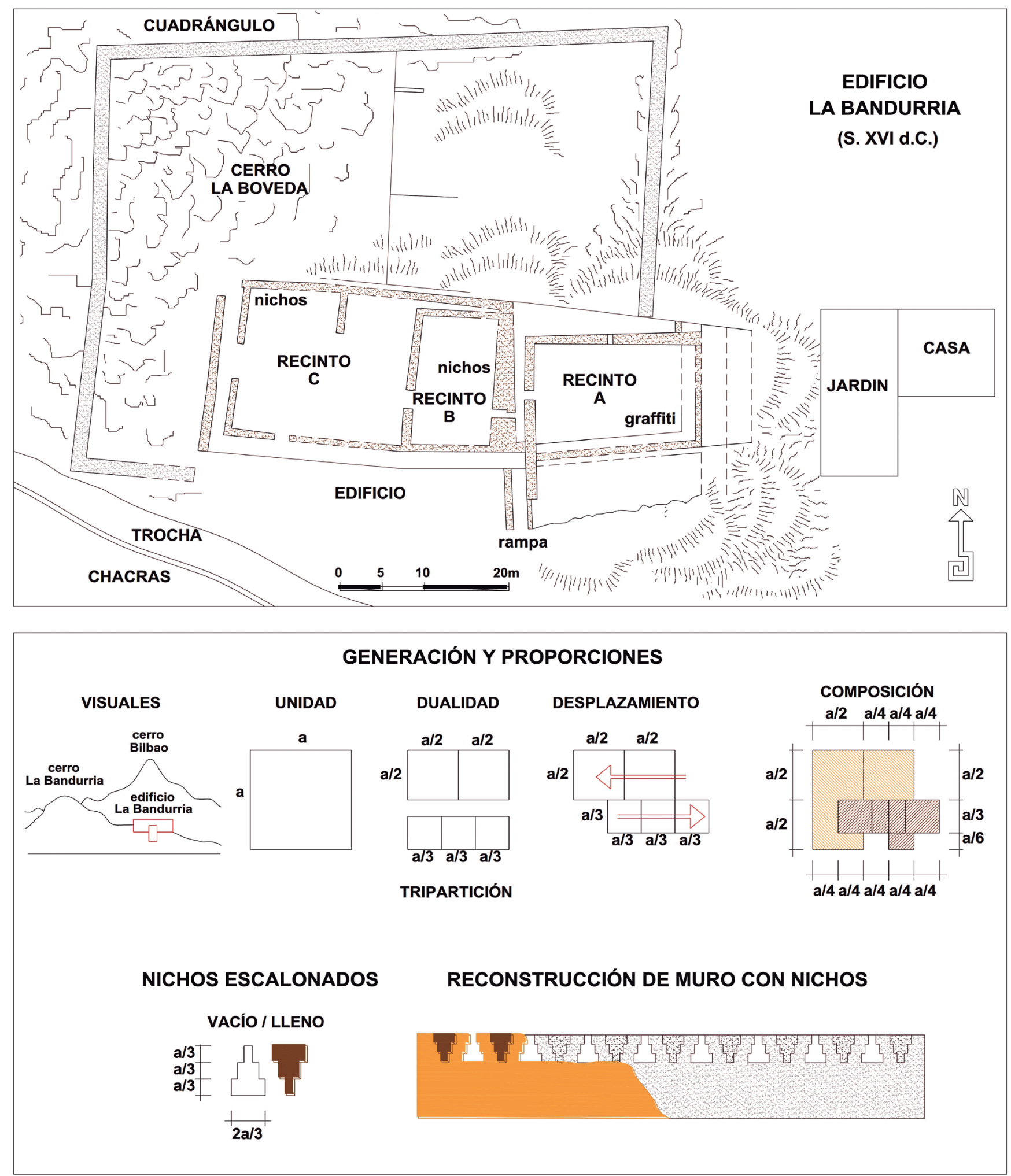

Figura 2. Planta del edificio La Bandurria. Se destaca su emplazamiento, la relación complementaria entre el volumen y espacio (edificio-cuadrángulo), y la tripartición interna en tres recintos.

Fuente: Elaboración propia, Jorge Alvino y Miguel Guzmán, sobre los levantamientos realizados entre 2004 y 2006. 


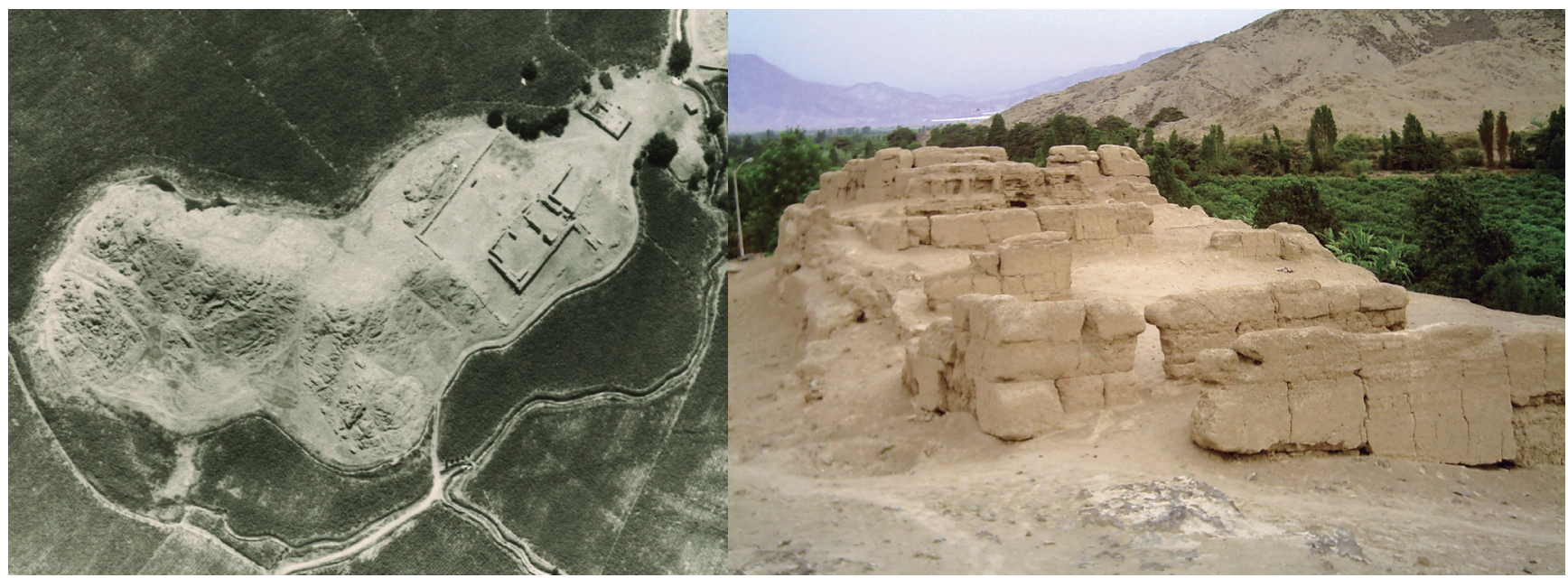

El sector oeste señalado está conformado por dos grandes recintos (Figura 2), uno cuadrangular (recinto $\mathrm{C}$ ) y otro rectangular (recinto $\mathrm{B})^{2}$. El primero mide aproximadamente $20 \times 17$ metros y presenta un muro transversal (norte-sur) en la parte media del muro norte, por lo que está subdividido internamente en dos partes que guardan una relación proporcional entre sí (10 x 17 metros). El segundo recinto, que claramente tiene una proporción similar, cuenta con una orientación longitudinal norte-sur que podría percibirse como complementaria a las anteriores, de tal manera que se tendría una organización tripartita. Este recinto (B) se encuentra a un nivel de piso superior, y se caracteriza además por la conformación de su muro este, a partir del punto donde existe un ingreso desde el pasaje norte-sur: se trata de un gran doble muro que cuenta con seis nichos cuadrangulares (de aproximadamente 70 centímetros de lado) entre los cuales se intercalan nichos rectangulares muy delgados en su parte vertical, en suma un total de 11 nichos (los del lado sur en muy mal estado de conservación).

\section{Nichos escalonados}

Sin embargo, el que tal vez es el detalle más importante se ubica en el muro norte del recinto $C$ : la secuencia de nichos escalonados (Figura 6). El recinto oeste (C) se encuentra desnivelado por el deterioro general del relleno interno; la gran mayoría de sus muros perimetrales han colapsado, pero aún se mantiene en pie la esquina noroeste, que en su muro norte posee una serie de nichos de particular trazado: su alzado presenta un perfil trapezoidal escalonado. El primero, desde la base menor hacia la mayor, se encuentra cerrado (no traspasa el muro de tapial), pero el siguiente es escalonado desde la base mayor hacia la menor y se encuentra abierto (traspasa el muro). Esta alternancia se repite en todos los subsiguientes; en total son cinco nichos (quizás seis) que siguen este diseño. Es muy posible que todo el muro haya tenido este tipo de tratamiento, por lo que (de acuerdo a las medidas y proporciones de los nichos, y la longitud total de la base del muro) pudieron sumar originalmente un total de 17 nichos (ocho abiertos y nueve cerrados). De acuerdo al registro realizado, las proporciones existentes en la muestra mantienen el sistema de proporciones y ordenamiento existente en la planta del edificio (Figura 2).
Figura 3. Foto aérea de La Bandurria. Destaca el afloramiento rocoso y el edificio de La Bandurria, Ilamado también El Templete, junto con un cuadrángulo de tapia.

Fuente: Servicio Aerofotográfico Nacional, 1945

Figura 4. Vista general del edificio La Bandurria. Destacan su elevación y el sistema constructivo de tapias. Al fondo el cerro La Bóveda y las chacras de Caqui

Fuente: Archivo fotográfico Carlos Alvino, 2006.

2. Ver también los planos y las descripciones presentadas por Guzmán (2016, p. 124-131), donde se han nombrado los recintos de la plataforma superior, de oeste a este, como "recinto 1. Patio principal", "recinto 2" y"recinto 3". Se señalan también los detalles característicos de las hornacinas, y los nichos escalonados e invertidos (muro norte del recinto 1) y los cuadrangulares (muro este del recinto 2). 


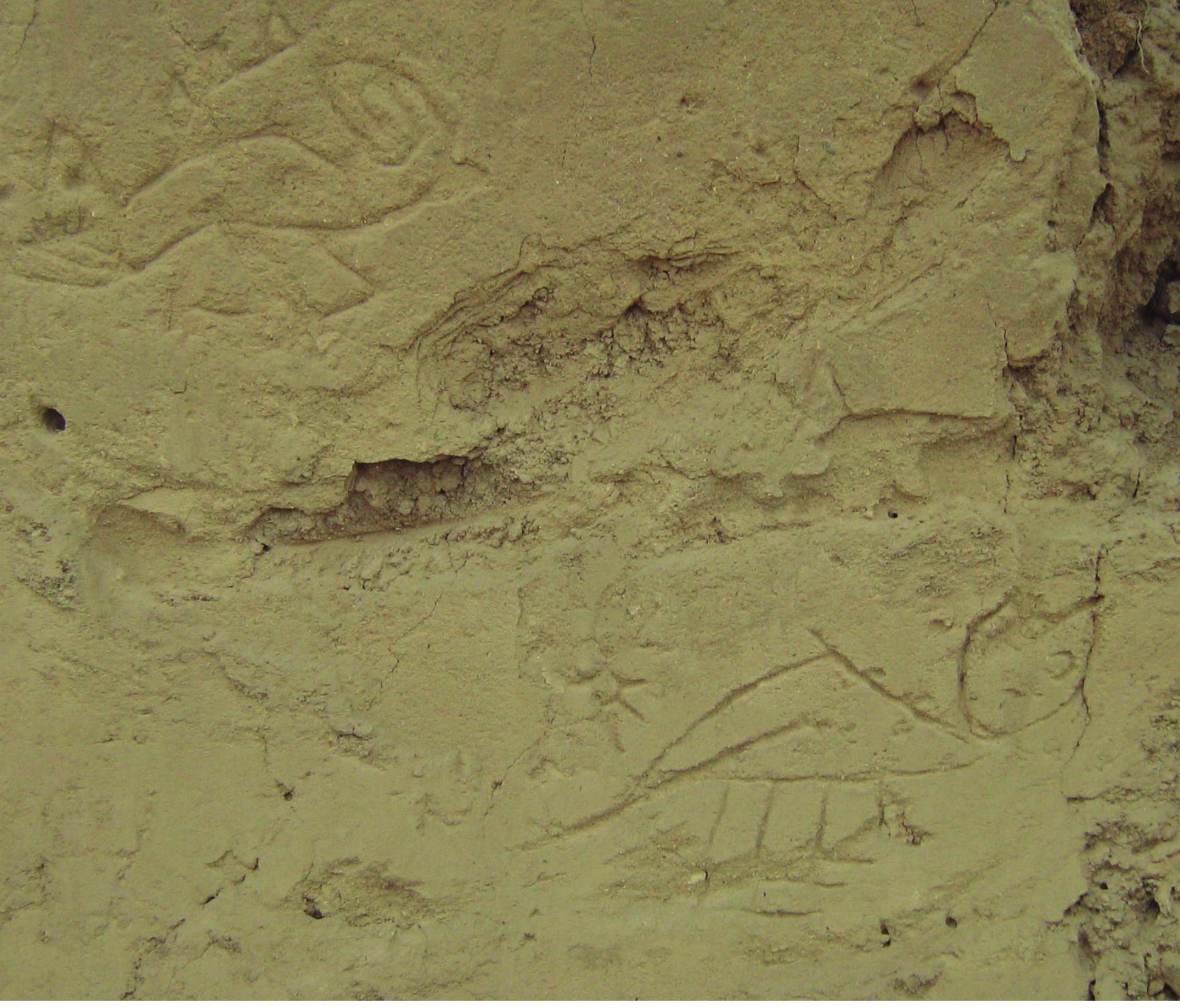

Figura 5. Detalle de los grafiti de los tres felinos (el segundo destruido recientemente) sobre una pared en un pasaje posterior del edificio La Bandurria

Fuente: Archivo fotográfico Carlos Alvino, 2006.

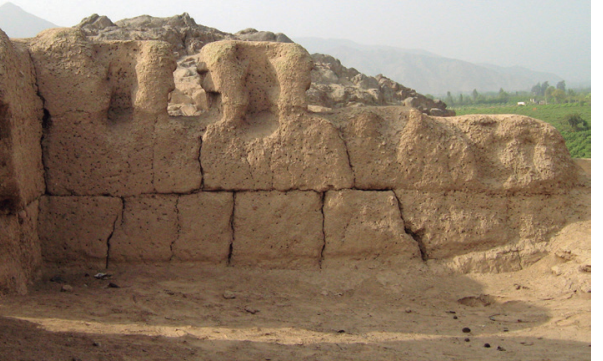

Este trabajo murario es un rasgo significativo de la importancia de edificios como La Bandurria; su presencia no es común en los sitios chancay del valle, aunque sí existe en muchos sitios que tienen comprobada presencia del Tawantinsuyu, es decir, ocupaciones del Horizonte Tardío (1470-1533 d.C.) en la costa central, como por ejemplo en Tambo Colorado (Pisco), Ungará e Incahuasi (Cañete), Uquira (Asia), etc. Por lo tanto, este podría considerarse un rasgo arquitectónico presente en los edificios más importantes construidos durante la expansión de la sociedad quechua, lo cual permitiría proponer a Caqui como un sitio administrativo cusqueño en el valle bajo del río Chancay.

\section{Los graffitis}

Hacia la esquina sureste del edificio se ubica un pasaje que rodea la plataforma superior (similar al pasaje que pudo existir hacia la esquina suroeste); sobre la pared interna existen aún algunos grafitis ${ }^{3}$ en la superficie alisada. Se trata de tres pequeñas formas

3. Grafiti proviene del italiano graffit o graffire, y éste del latín scariphare (que significa incidir con el scariphus -estilete o punzón-) y se refiere a las escrituras sobre tablas dentro de contextos urbanos. La característica de un grafiti es el trazado de diseños sobre las paredes de edificios de manera espontánea y libre, con la finalidad de transmitir mensajes que impacten visualmente. 
figurativas ordenadas de manera vertical y sucesiva. Todas fueron elaboradas de manera rápida y precisa por medio de un punzón, buril o instrumento con punta cuya sección no era mayor de un centímetro, a juzgar por el ancho de los trazos; también es posible identificar que la profundidad es uniforme y no existen restos de material sobrante o extraído, por lo que puede deducirse que fueron limpiadas posteriormente al secado. Las imágenes, si bien parecen ser naturalistas de manera general, lo son en realidad en cuanto a sus rasgos o partes, los cuales se combinan y producen finalmente una imagen icónica compuesta quizás a partir de tres figuras reconocibles, que sintetizan en todos los casos el perfil de un felino (Figura 5).

Grafiti A. Está compuesto de tres formas sintéticas reconocibles: una cabeza triangular con dos triángulos, con dos puntos en la parte inferior de los mismos, que la coronan. Un pequeño desprendimiento parece coincidir con lo que pudo ser una boca y los dientes respectivos. Asimismo, una continuidad formal podría corresponder a un cuerpo figurativo de forma semicurva, del cual se desprenden hacia la parte inferior unas líneas a modo de extremidades inferiores y hacia la parte superior una línea sinuosa que se asocia a tres pequeños triángulos sucesivos. El remate de la figura es una espiral de dos giros hacia su interior; la orientación de la figura parece ser de izquierda a derecha.

Grafiti B. Lamentablemente casi completamente destruido en épocas recientes. La única parte que aún existe parece corresponder a una extremidad inferior que termina en unos apéndices a modo de garras.

Grafiti C. Corresponde a una figura similar a la del grafiti A, pero la cabeza tiene forma más hexagonal, presenta ojos en círculo (quizás producidos por la impresión de una caña) y la boca está apenas insinuada. El cuerpo está trazado de manera más geométrica y angulosa; es casi un triángulo con el ángulo mayor hacia arriba (o cúspide del lomo); en este caso de la parte inferior del cuerpo se desprenden cuatro líneas quebradas paralelas dispuestas en orden de tamaño, que parecen representar las extremidades inferiores. La orientación de esta figura, al contrario de la del grafiti A, parece ser de derecha a izquierda.

A pesar de que se asume una interpretación básicamente figurativa a partir de la evidencia hallada, es indudable que la imagen descrita (el felino) es importante dentro de la cosmovisión andina, especialmente en las sociedades costeras; por otra parte, su ubicación (en un lugar secundario y casi escondido del edificio) podría suponer la pervivencia de creencias locales chancay frente a la ocupación de la sociedad cusqueña y la implantación de nuevas ideologías. Felinos en la costa han sido representados desde hace 4,500 años en Huaca Prieta, por ejemplo, y posteriormente en sitios como Sechín, Punkurí, Garagay, Huaca de la Luna, y muchos otros; estos adquieren, en las pinturas y esculturas polícromas, la categoría de una deidad central. En el caso de la cultura chancay aparecen generalmente en representaciones textiles, tanto en tapices como en gasas, pero de manera especial en telas pintadas, donde estilísticamente son representados con el cuerpo de perfil y la cara vuelta hacia el espectador, el lomo encorvado, la cola en espiral y las orejas de forma triangular (Figura 7). Aun así, la figuración realista puede superponerse o combinarse con otras formas naturales o seminaturalistas, en este caso, por ejemplo, con la serpiente, con la que comparte ciertos rasgos, como la forma curva o espiral.

Ideológicamente, a diferencia del Ilamado choquechinchay (felino luminoso) que precedía las lluvias en la sierra, el felino de la costa, durante la vigencia chancay, aparentemente era un personaje secundario o un asistente de una deidad central asociada a la muerte (Figura 8), quizás por ciertas cualidades inherentes: "se transforma en un ser que ve (todo), que conoce el bien y el mal y que, por eso mismo es divino, inscribiéndose en el dominio de la sinuosidad por sus caricias, en el de la angularidad agresiva por sus garras, en el círculo por su mirada; después de someterse a la ortogonalidad de nuestra imaginación racional" (Joly, 1982, p. 142).
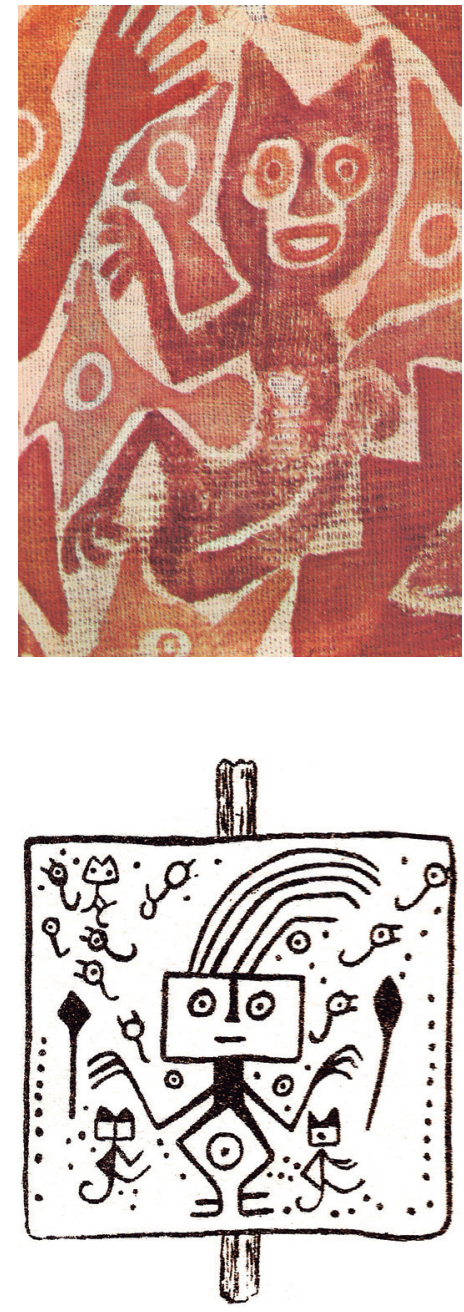

Figura 6. Vista del muro de tapia con los nichos escalonados que aún subsisten en La Bandurria. Destacan la alternancia, y los efectos de luz y sombra. Al fondo el cerro Bilbao

Fuente: Archivo fotográfico Carlos Alvino, 2004

Figura 7. Detalle de un textil chancay con representación de felino

Fuente: De Lavalle \& Lang, 1982, p. 139.

Figura 8. Dibujo de una escudilla chancay proveniente de un contexto funerario. Los felinos acompañantes de un personaje central se representan de manera sintética Fuente: Carrión, 1959, p. 140. 


\section{La casa hacienda Caqui}

La casa hacienda Caqui se encuentra en la margen izquierda del valle bajo de Chancay, a una altura aproximada de 246 m.s.n.m. Se emplaza sobre un afloramiento rocoso que se desprende de la formación geológica conocida como cerro La Bóveda, que sobresale del llano del valle y es visible sobre el cono de deyección del mismo. Si se observa su ubicación (Figura 1), Caqui se encuentra prácticamente en la parte media del valle, cercana al río, por lo cual los terrenos adyacentes son bajos y se encuentran continuamente irrigados por medio de canales, que son los que limitan los terrenos de las parcelas y propiedades de las haciendas.

Respecto al origen de la hacienda se han llevado a cabo algunos estudios, aunque a diferencia de otras importantes en el mismo valle (Palpa, Huando, Retes, Laure, etc.), los datos de la hacienda de Caqui aún no han sido definidos (Keith et al., 1970). Lo que se sabe es que Caqui (junto con otra pequeña hacienda, Ilamada Jesús del Valle) era un anexo de la hacienda La Huaca, la cual era administrada por los jesuitas, y pertenecía al corregimiento de Chancay. Además, por referencias secundarias, se sabe que hacia el siglo XVIII la hacienda mantenía una ingente cantidad de esclavos. En 1767, a consecuencia de la expulsión de los jesuitas del Virreinato del Perú, todas sus haciendas (entre ellas la de Caqui) fueron repartidas y expropiadas por la Corona. No se conoce exactamente cómo fue vendida; tuvo diversos dueños hasta llegar a manos de Pedro Castro Saldívar (Cajamarca, 1798-1858). Es este último dueño quien mandó construir la casa hacienda (Ministerio de Educación, 2007), que en 1871 pasó a poder de Jerónimo Sánchez, vecino del poblado de Aucallama, quien allí desarrolló producción de algodón junto a sus hijos hasta 1897 (Ministerio de Educación, 2010). Ya en el siglo XX, exactamente en 1914, tanto Manuel Mujica Carassa como su esposa Victoria Gallo Porras ${ }^{4}$ eran dueños de la hacienda Caqui. Su hijo, Manuel Mujica Gallo, nacería en 1906, y la hacienda seguiría en poder de la familia desde 1926 hasta 1942. Esta contrató como administrador a Nikumatsu Okada, empresario japonés que arrendó numerosas haciendas en el valle, hasta que fue deportado a Estados Unidos debido al estallido de la Segunda Guerra Mundial. Entonces, los Mujica volverían a administrar la hacienda hasta la Reforma Agraria, en 1968.

Las haciendas en Chancay tuvieron particularmente mucho éxito por el cultivo de maíz en tiempos del Virreinato, y durante la República ampliaron su economía hacia la producción de algodón y productos frutales. Fueron numerosas, distribuidas a lo largo de ambas márgenes del valle bajo, y lograron tener una fuerte autonomía con respecto a Lima, incluso. Las ciudades de Huaral y Chancay se desarrollaron en función a la actividad económica de las haciendas; la llegada del tren (recién hacia 1880) solo impulsó más estas posibilidades, pues las articulaba directamente con los embarques marítimos. El poder de las haciendas siguió siendo muy fuerte hasta la década de 1960, y las familias que las poseían eran las más 'notables' de la aristocracia peruana. Con la Reforma Agraria este sistema económico se desarticuló abruptamente, y la economía que sustentaba las casas hacienda, así como sus benefactores, desapareció. Las mansiones campestres fueron abandonadas, y en pocos años fueron saqueadas y desmanteladas. En algunas de ellas, sin embargo, aún permanecen restos de su antiguo esplendor, como es el caso de la casa hacienda Caqui, la cual, aunque fue (y sigue siendo) despojada de sus bienes y consistencia material, aún conserva expresiones artísticas inherentes al inmueble mismo: las pinturas murales, que se encuentran en gran cantidad en distintos sectores de este antiguo edificio.

4. El padre de Victoria, Miguel Gallo Díez, nació en Esalada (Burgos) en 1856 y se casó en 1878 con Elvira Porras Bolívar. A fines del siglo XIX tenía propiedades mineras en el Perú, además de muchas haciendas, entre las que contaba Caqui. Miguel Gallo murió en Madrid en 1918, y heredó sus propiedades a sus hijos (Martínez, 2006), 

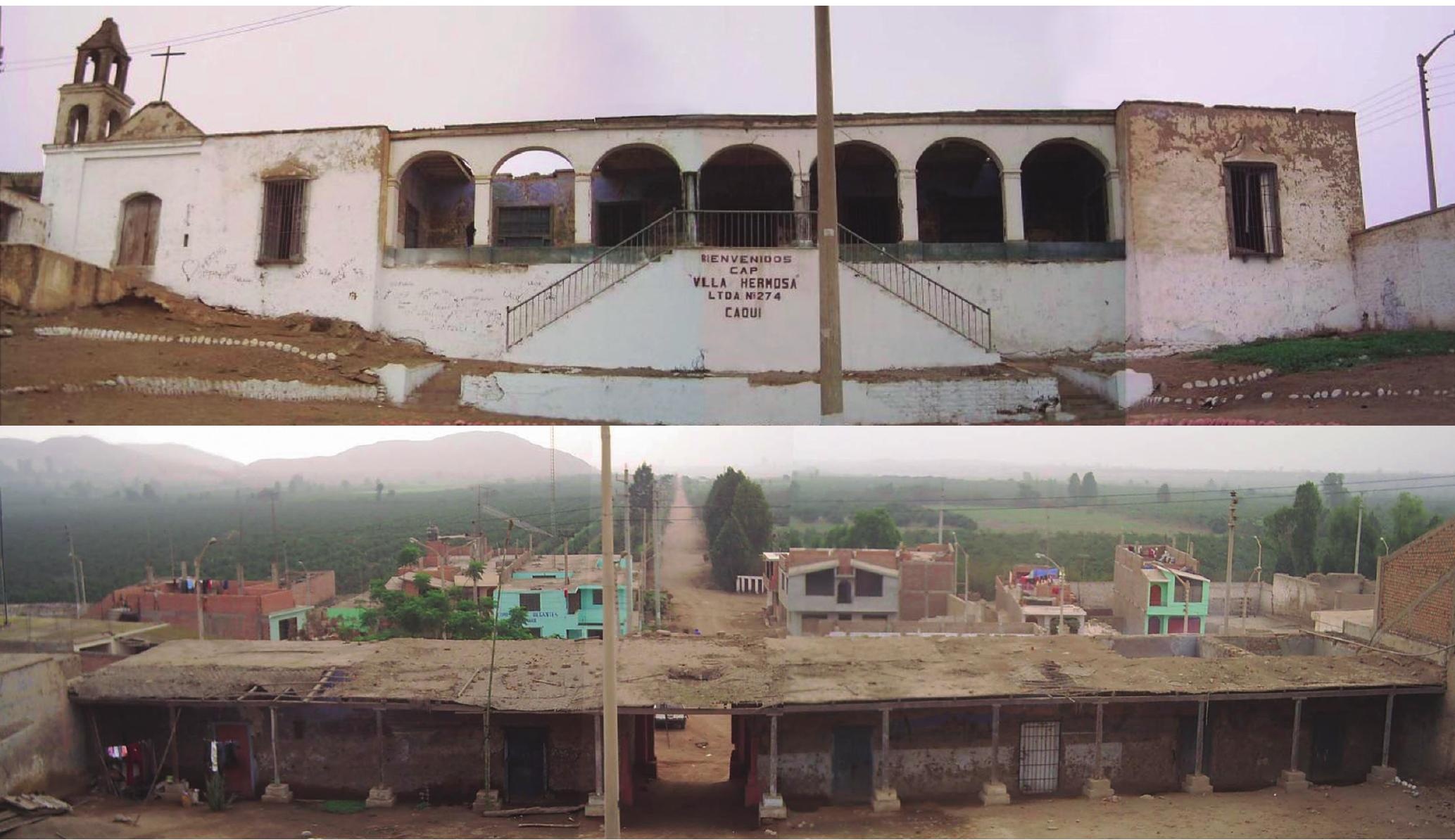

\section{Tipología arquitectónica}

La 'hacienda' en el Perú fue uno de los principales ejes económicos durante la República; se sustentaba en la capacidad administrativa de parte de grupos de poder o familias notables que, si bien residían permanentemente en las grandes ciudades como Lima, Arequipa o Trujillo (solo por citar las costeras), se permitían construir en pleno campo no solo una gran casa hacienda para sus visitas administrativas a sus fundos, sino también todo un complejo casi industrial para el procesamiento de sus bienes.

La tipología arquitectónica del edificio de la casa hacienda de Caqui corresponde principalmente a una función de residencia doméstica (cocina, comedor, servicios higiénicos, etc.), en la cual los espacios se encuentran distribuidos alrededor de un patio central que les proporciona luz y ventilación, y que además los independiza. También la casa, al ser reservada para cobijar al hacendado y su familia durante sus visitas, cuenta con espacios que facilitan el manejo de la hacienda misma, es decir, oficinas y salas de recepción. Así, incluye un zaguán, un patio principal, un atrio de ingreso y una capilla, espacios que cuentan con una infraestructura especial, y en los que se ha aplicado cuidado en el diseño y la decoración. En el plano del edificio (Figura 11) se encuentra achurada el área estudiada.

Las casas hacienda fueron los lugares donde se concentraba además un tipo de arquitectura propia, similar a las grandes casas de morada mayor de Lima, y también albergaban numerosas obras artísticas, como muebles, cuadros y esculturas importadas de distintos lugares del mundo. Eran, pues, mansiones de lujo en medio del campo; este tipo de contraste no existía en las grandes ciudades peruanas.
Figura 9. Vista hacia el oeste desde el atrio de la casa hacienda de Caqui. Destaca el trazo recto del camino que atraviesa el valle

Fuente: Archivo fotográfico Carlos Alvino, 2006

Figura 10. Vista general de la escalera, atrio y capilla. La horizontalidad y composición es propia del neoclásico

Fuente: Archivo fotográfico Carlos Alvino, 2006 
devenir Vol. 3, N6, JULIO-DICIEMBRE 2016, PP. 143-162 - EsTUDIOS I ISSN 2312-7570

UNIVERSIDAD NACIONAL DE INGENIERÍA, LIMA

Figura 11. Planta general de la casa hacienda Caqui. La simetría y axialidad es similar a las casas urbanas; sin embargo, la escala de sus patios y el dominio visual del entorno, distingue su carácter campestre.

Fuente: Elaboración propia, 2016.

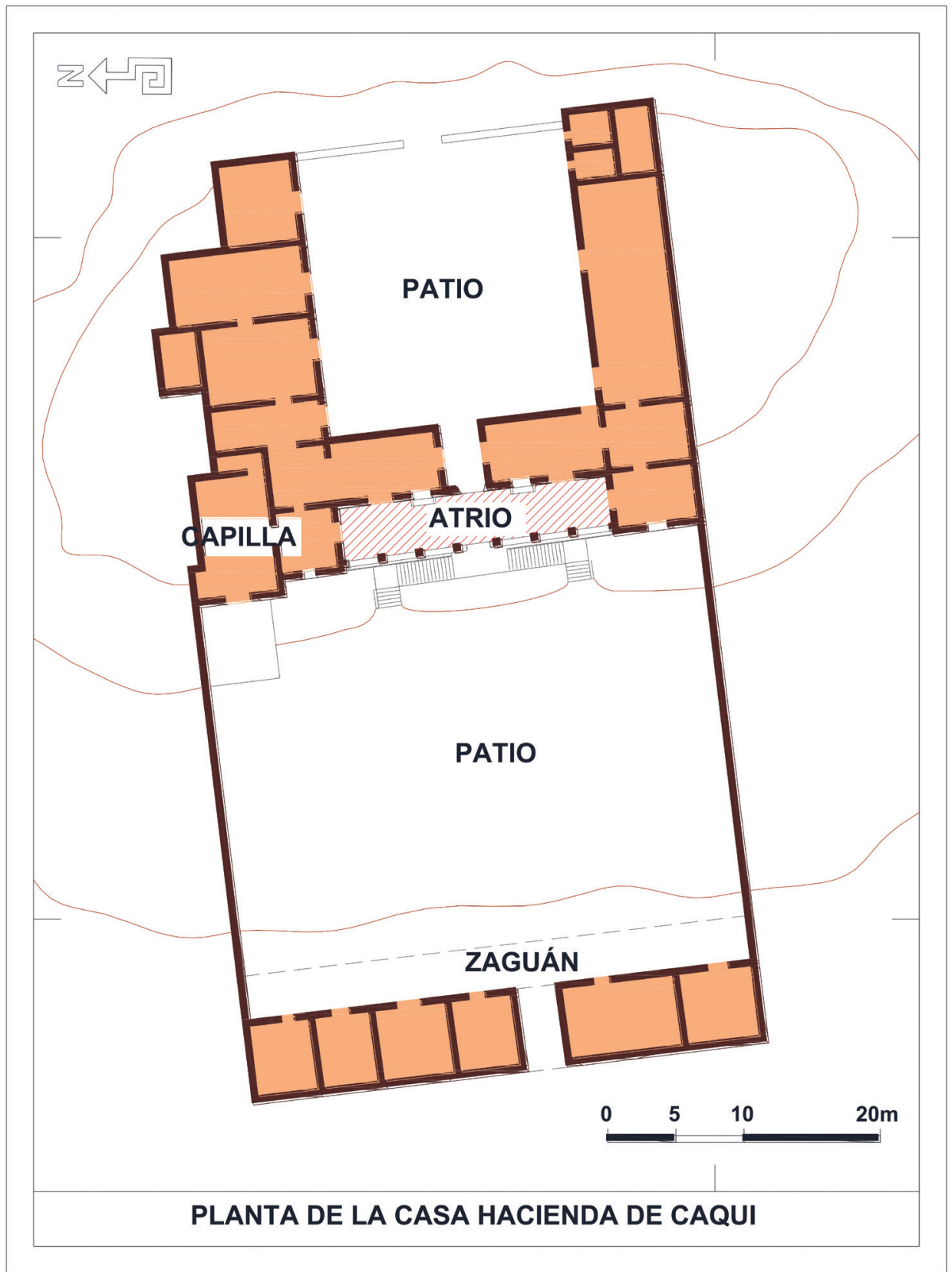

\section{La capilla}

Adyacente a su lado norte se encuentra la capilla de la casa hacienda, la cual parece haber sufrido distintas remodelaciones. Su fachada es de un solo cuerpo, con cornisa simple y rematada en un frontón triangular con una sencilla cruz en su cúspide; la única torre que posee es de dos cuerpos con aberturas en todos sus lados y ya no presenta la campana (quizás sustraída); asimismo, el techado es muy similar a los mojinetes del sur del país. Toda la capilla ha sido construida con adobes y quincha, mientras que el techado inclinado es de madera.

En el interior la temática de las pinturas es exclusivamente cristiana; ratifica el Nuevo Testamento y los principios de la Contrarreforma, lo cual contrasta con las pinturas del 
atrio o del patio. Aun así, se advierte que no se mezcla símbolos cristianos con profanos; más bien se reservan para estos espacios muy diferenciados dentro de la misma casa hacienda. Esta zonificación propiamente neoclásica se desvincula de otros contextos asociados al barroco andino, donde existen símbolos combinados, como en la iglesia de Rapaz (Oyón, Lima): El arte al interior de la referida iglesia incluye motivos religiosos cristianos, de la mitología greco-romana y nativos, cuyo tratamiento estético permite valorarlos como expresión de un arte barroco denominado Estilo Mestizo (Ruíz, 1983).

En el interior de la capilla existen en casi toda la extensión de sus paredes pinturas murales. Siguiendo un ordenamiento de las pinturas, tanto espacial como temáticamente, se ha podido agruparlas en cuatro conjuntos (Alvino, 2016): i) Cristo yacente en la parte baja del altar (Figura 12), pintura que probablemente realizó un artista distinto al que ejecutó las del atrio, pues existe una diferencia en el trazo pictórico; ii) las pinturas dedicadas a la vida de Jesús, desde su nacimiento hasta la última cena (Figura 13), además de otros episodios donde aparecen algunos personajes importantes, como la Virgen María o los apóstoles; iii) las referidas a las virtudes teologales -fe, esperanza y caridad-; y iv) el Cristo crucificado, pintado en una de las paredes de la sacristía.

\section{El patio principal}

El espacio más grande de toda la casa hacienda corresponde al patio principal, el cual se encuentra en la parte delantera y ocupa todo el ancho del frente de ingreso. Desde el exterior se accede al patio por medio de un zaguán (el cual parece ser uno de los sectores más antiguos del inmueble) que posee dos arcos rebajados. La primera crujía longitudinal está ocupada por una serie de recintos, quizás destinados a tiendas o depósitos (actualmente han sido invadidos por pobladores). Tanto las paredes del zaguán como las del patio mismo se encuentran decoradas con amplios frescos que representan paisajes, tanto marinos como urbanos (Figura 14). Destacan, por ejemplo, puertos e islas donde ondean banderas de Francia, Inglaterra y Barbados. También existen dos pinturas en ambos lados de las paredes del zaguán, que representan escenas campestres de paseo. Hacia el Este, frente al zaguán, cerrando el patio, se eleva el atrio como fachada principal del cuerpo; sus líneas evidencian un diseño geométrico de estilo neoclásico, lo cual refuerza su color blanco (Figura 10).

\section{El atrio de la casa hacienda}

El atrio corresponde al espacio central ubicado en el eje longitudinal de la casa hacienda. Desde su ubicación elevada se domina visualmente todo el valle bajo, hasta la línea del mar; es, por esta razón, también visible desde el entorno (Figura 9). A él se accede por una doble escalera de dos tramos, construida de ladrillo pastelero y actualmente revestida de cemento. Posee dimensiones de 17 metros de largo y 4 de ancho por 3.60 de alto. Los lados norte y sur están flanqueados por los cuerpos laterales de la edificación mayor de la casa y abren hacia dos oficinas; el lado este se encuentra delimitado por tres recintos; el central es un corredor abierto que abre y comunica el espacio hacia el patio posterior; y los otros dos recintos, casi idénticos, poseen puertas y ventanas que abren al atrio. Entre los paños que existen entre estas puertas y ventanas, sobre un zócalo pintado, se ubican las áreas donde se plasmaron las pinturas murales analizadas (las del gran muro este). El atrio, además, tiene el lado oeste abierto por medio de una fila de dos pilastras y seis columnas de quincha, unidas todas por un muro bajo que deja un acceso al medio de las mismas (Figura 10).

Todo el atrio, así como las columnas y los arcos de medio punto, se encuentran pintadas de blanco, lo cual destaca desde lejos sobre el llano verde. Es necesario indicar que los marcos de las puertas y ventanas, así como el mobiliario posteriormente añadido (bancas), el zócalo y el fondo mismo de las pinturas, se encuentran pintados en un tono azul ultramar, lo que le da a todo el conjunto del atrio unidad de tonalidad y contrasta con el blanco aplicado a las demás formas arquitectónicas (Figura 15).
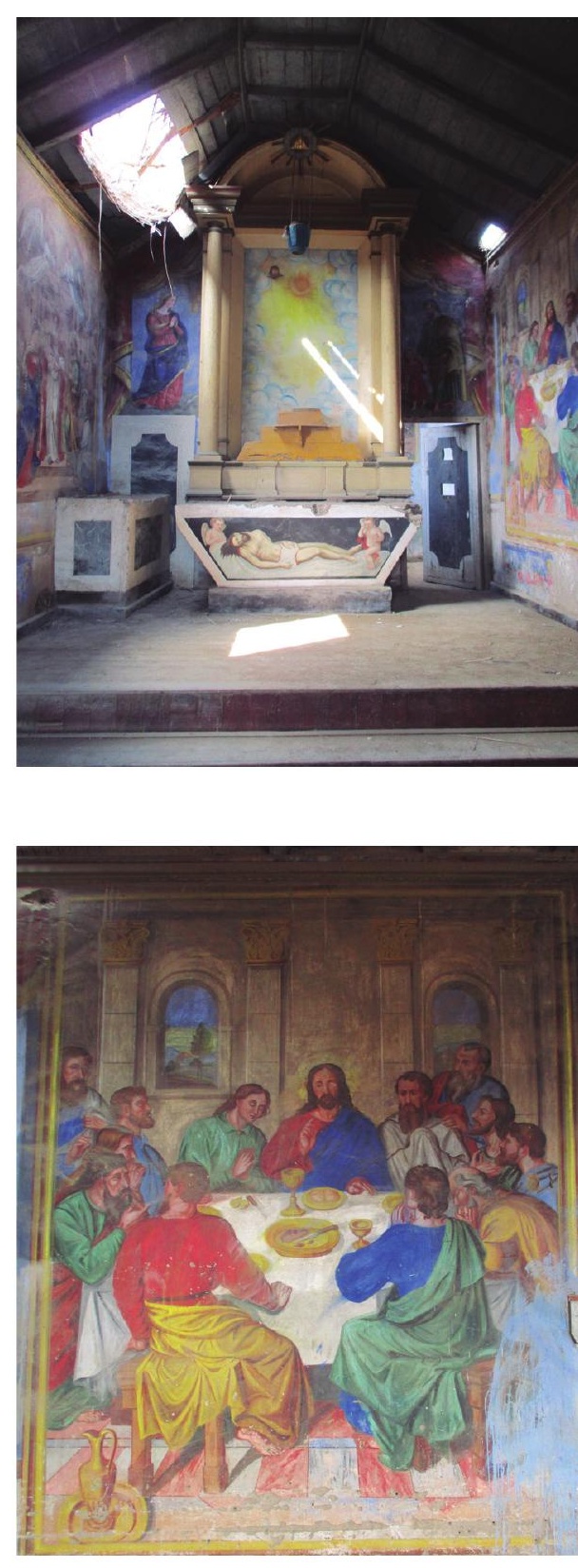

Figura 12. Capilla de la casa hacienda, completamente cubierta de pinturas murales que representan pasajes del Nuevo Testamento. Al fondo el altar con la figura de un Cristo yacente y el retablo completamente saqueado

Fuente: Archivo fotográfico Carlos Alvino, 2016

Figura 13. Pintura sobre La Última Cena, una de las más grandes, actualmente dañada

Fuente: Archivo fotográfico Carlos Alvino, 2016. 


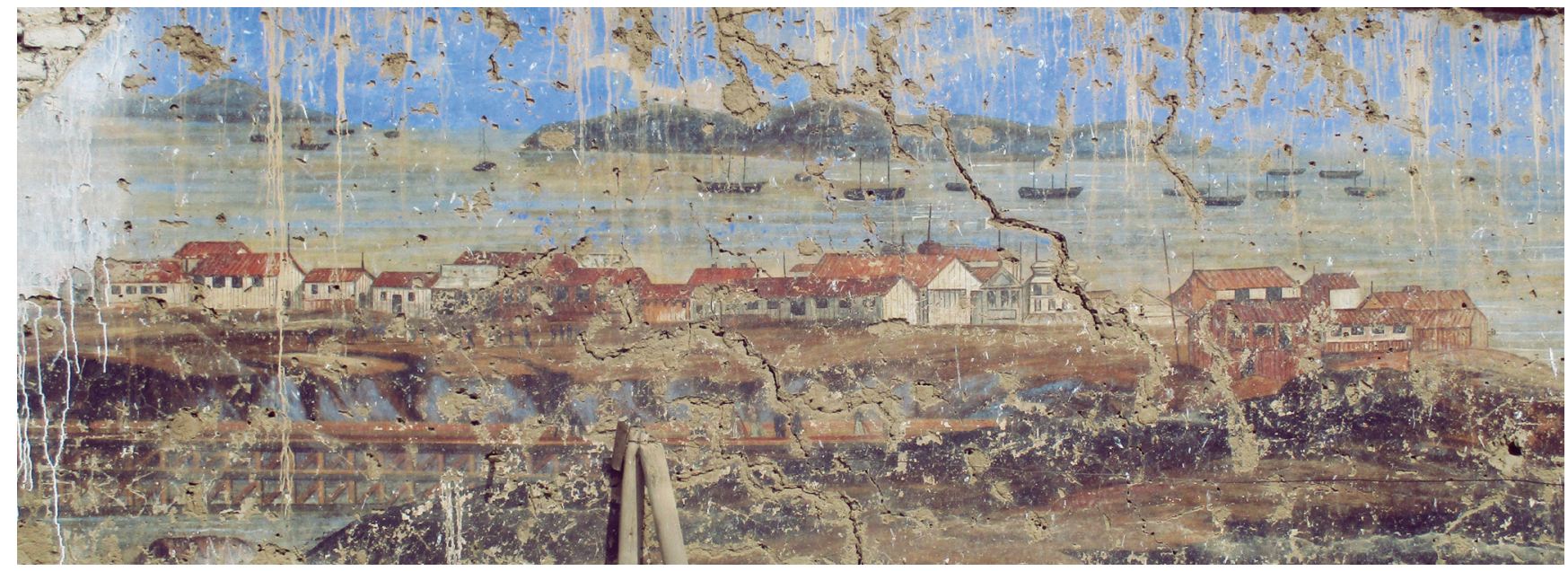

Figura 14. Pintura mural del primer patio. La temática tiene que ver con paisajes urbanos y litorales, principalmente de lugares europeos; En este caso pudiera ser un balneario o puerto peruano, quizás Ancón.

Fuente: Archivo fotográfico Carlos Alvino, 2016.

Figura 15. Vista interna del atrio con las pinturas en conjunto. Hasta 2006 se mantenían casi intactas la carpintería y cerrajería. Durante las últimas ocupaciones se cambió gran parte del piso machihembrado original y se modificó varios ambientes interiores.

Fuente: Archivo fotográfico Carlos Alvino, 2006.

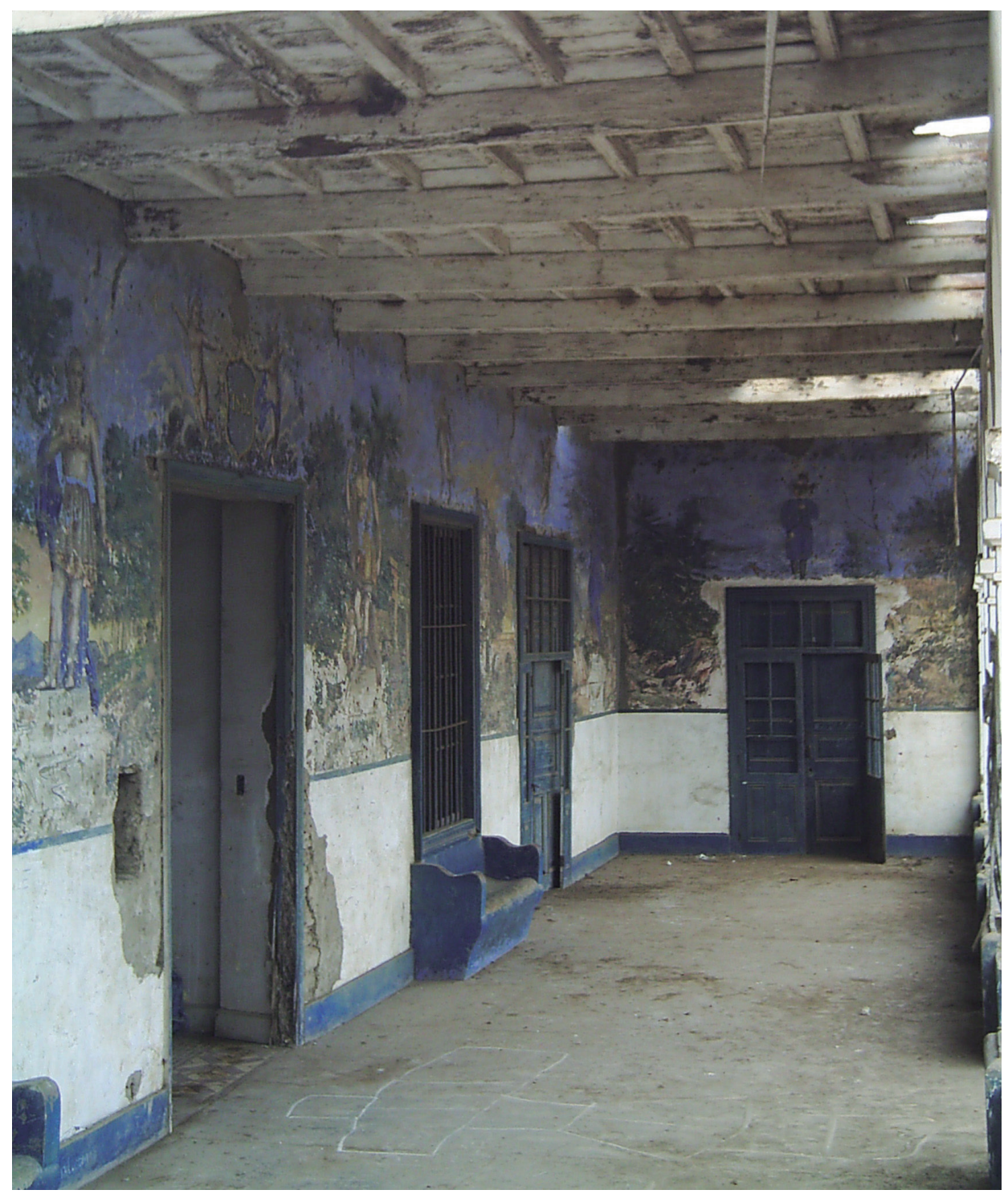




\section{DISTRIBUCION DE IMAGENES}
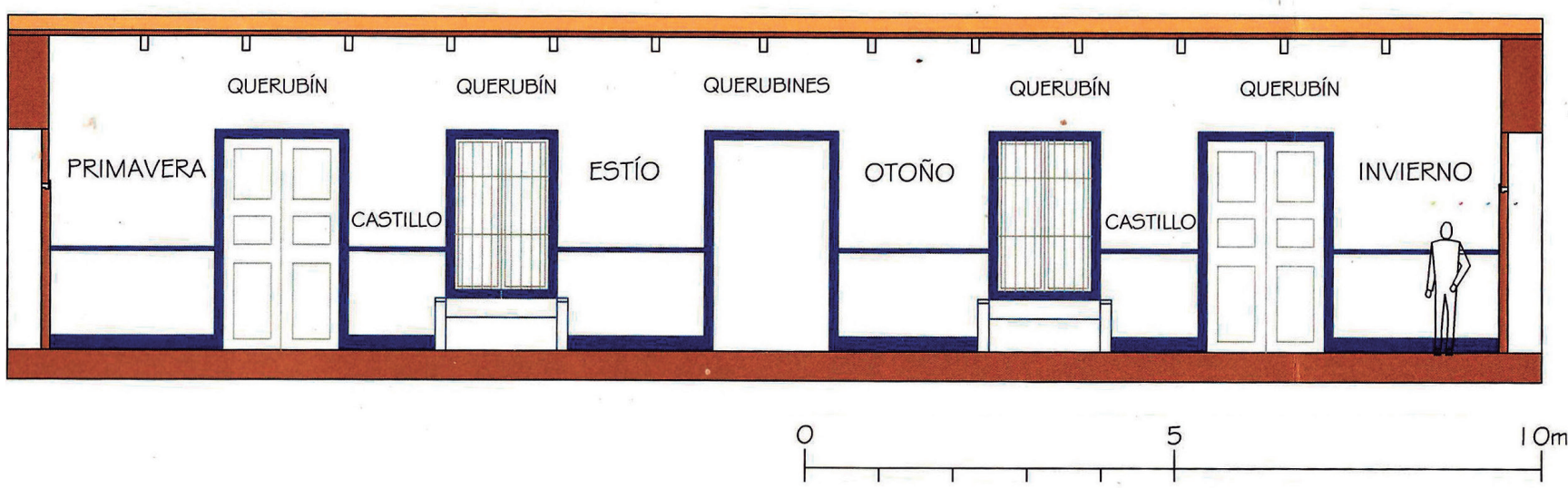

\section{Las pinturas del atrio}

La pared se encuentra casi completa, a excepción de algunos faltantes propios del estado de conservación. Constituye una muestra íntegra de una temática que se ha identificado como 'Las Cuatro Estaciones', tema muy vinculado a la naturaleza y al contexto circundante; finalmente, cabe señalar que como obra pictórica es una obra completa, íntegra y original.

Las cuatro estaciones han sido pintadas en una pared orientada al Oeste, la cual posee dimensiones de 19.75 metros de largo y 4.25 de alto; esta pared es la parte exterior de un muro de adobe que separa el atrio de los principales recintos interiores de la casa hacienda. Este muro se caracteriza por poseer tres vanos de acceso, cada uno hacia distintos espacios. Como se ha indicado anteriormente, los otros dos vanos corresponden a áreas de iluminación, y en todos los casos presentaban hasta el año 2006 una carpintería de ventanas y puertas de madera de doble hoja. La parte baja de los muros ha sido reservada sin decorar hasta una altura aproximada de 1.30 metros, por lo que posee un enlucido blanco, al cual ha sido añadido un contrazócalo bajo moderno pintado de azul. De esta manera, sin incluir los vanos y zócalos, él área decorada que se puede considerar como parte integrante de la obra pictórica mural posee un aproximado de $43.14 \mathrm{~m}^{2}$. Sin embargo, debido a la existencia de los vanos arriba mencionados, el soporte mural no es continuo, a excepción de las superficies superiores a los dinteles de los vanos. Por esta razón se ha considerado esta primera limitante como parte del análisis, pues interviene directamente en la composición artística y el diseño de las formas de las imágenes.

Por medio del levantamiento realizado y con apoyo de fotografías se puede establecer la distribución de las imágenes correspondientes a cada sector del muro (Figura 16), que al presentar una disposición de vanos casi simétrica, favorece en gran medida la presentación temática de las cuatro estaciones, pues son precisamente cuatro los grandes lienzos que posee el muro. De esta manera, los cinco vanos existentes en el muro (dos puertas secundarias, una principal y dos ventanas) forman entre ellas seis paños libres (dos de los cuales son menores en ancho), además de los cinco paños existentes sobre los dinteles. Así, los 11 paños han sido decorados en su totalidad y están distribuidos de la siguiente forma:

- Cuatro paños inferiores grandes (Las Cuatro Estaciones)

- Dos paños inferiores medianos (dos paisajes con castillos)

- Cinco paños superiores pequeños (pequeñas efigies de amorcillos)
Figura 16. Alzado a escala del frontis principal del atrio con la distribución de las pinturas murales. Es interesante la equilibrada distribución de los llenos y vacíos, así como la sectorización de las pinturas en alturas.

Fuente: Elaboración propia, 2016. 

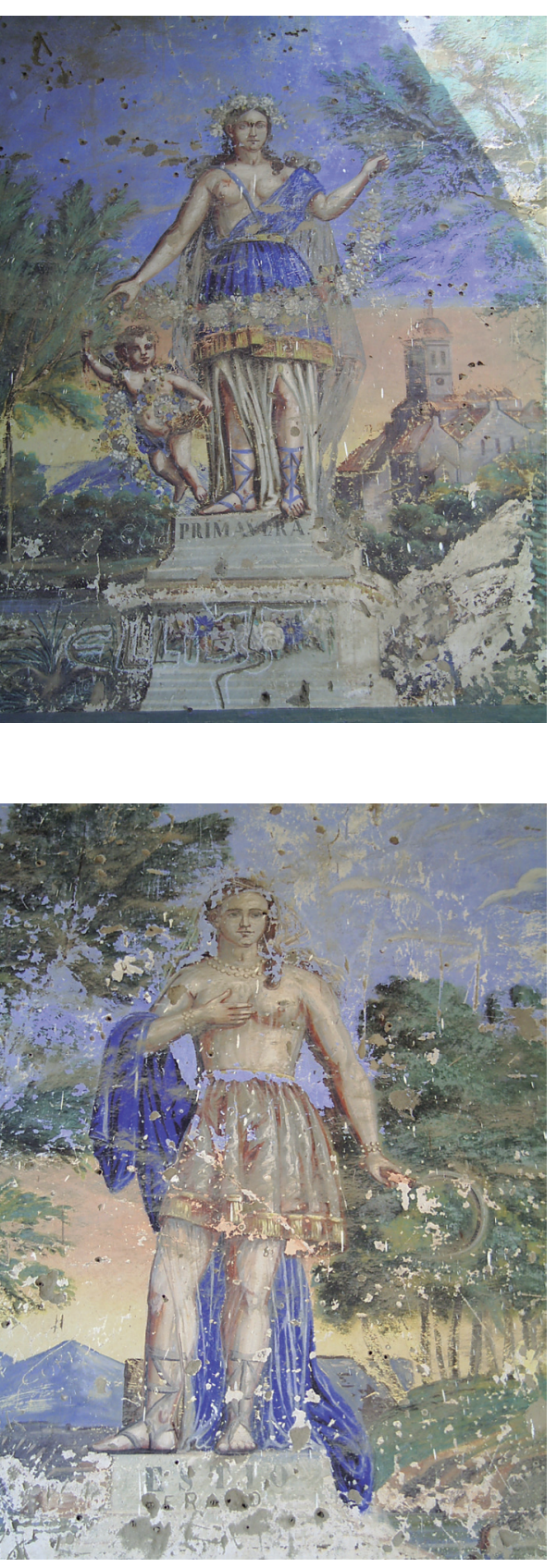

Figura 17. La primavera

Fuente: Archivo fotográfico Carlos Alvino, 2006.

Figura 18. El verano

Fuente: Archivo fotográfico Carlos Alvino, 2006.
Cabe mencionar que las pinturas son visibles incluso desde el exterior de la casa hacienda, aun estando bajo la techumbre que las protege del sol parcialmente; sin embargo, en las tardes de verano el sol cae casi directamente sobre la pared decorada y las columnas, lo que permite observar un fuerte contraste estético.

\section{Primavera (Figura 17)}

Está representada por una mujer que viste una túnica con capa larga, usa una corona de flores blancas y sostiene con sus manos extendidas una guirnalda de flores del mismo color. Esta imagen es la mejor conservada, por lo que se puede identificar el soporte de la mujer representada, el cual es muy similar a las bases de las estatuas neoclásicas: se apoya sobre un plinto y dos escocias, y es en el plinto precisamente el que lleva grabado el nombre de la estación correspondiente.

La primavera se encuentra acompañada por un niño situado a su izquierda, quien a sus pies parece alzar vuelo (aunque no se observan las alas, por lo que no parece ser un amorcillo) y sostiene, además de muchas flores, una antorcha dorada. El paisaje del fondo es interesante, pues muestra un gran edificio, posiblemente una abadía, con una torre cuya cúpula semiesférica remata en una linterna. Los vanos del edificio son breves, lo que le da apariencia de solidez románica; además, presenta muchos techos inclinados cubiertos de tejas. El paisaje circundante incluye árboles bajos pero frondosos, y unos cerros lejanos y azulados.

\section{Verano (Figura 18)}

El verano está representado por un hombre joven que acerca su mano derecha hacia su pecho mientras que con la otra sostiene una hoz, símbolo de cosecha agrícola. El joven solo viste un chitón con flecos, por lo que es el más descubierto de todos los personajes, aunque también sostiene una larga capa azul. Cabe destacar el collar que lleva sobre el cuello y lo corto de su cabello. En esta imagen existen partes deterioradas que no permiten registrarla en su totalidad; sin embargo, hacia la parte inferior está representado, en primer plano y en distinta escala, un grupo de personajes pequeños que parecen ser mujeres bañándose en un río. Esto podría relacionarse con el hecho de que es la temporada en la que existe agua en los ríos de la costa. El cielo azul y los contrastes con las tonalidades cálidas del atardecer son similares a los de la primavera; asimismo, los cerros son particularmente iguales; sin embargo, los árboles parecen ser más altos y cercanos.

\section{Otoño (Figura 19)}

Esta imagen, así como la del invierno, se encuentra a la derecha del acceso principal. Representa a un hombre joven que levanta un ramo de flores con la mano derecha y con la izquierda sostiene una vara, al parecer de metal, a modo de cetro. Cabe resaltar que tanto esta imagen como todas las representaciones humanas poseen los brazos muy sobredimensionados y en posiciones forzadas. Lleva además una corona de laureles y a sus pies se apoya un personaje mítico, un pequeño sátiro. El paisaje difiere de los anteriores: el personaje pareciera estar en un jardín o parque con fuentes, y un pórtico o arco de referencias orientales. En este caso el follaje es intenso y frondoso, e incluye algunas especies locales de la costa peruana.

\section{Invierno (Figura 20)}

El invierno es el último de la serie; está representado por un hombre viejo, de barba gris y casi totalmente cubierto por una capa azul. Lo acompaña como personaje secundario un águila de plumaje oscuro que aparece a sus pies, por detrás. En primer plano figuran en pequeña escala un grupo de hombres de vestimenta andina acompañados de camélidos, probablemente llamas, que se detienen a descansar a la vera de un camino. El paisaje lo conforma una extensión esteparia con una casa de tejados y torre apuntada; a lo lejos los cerros ahora son montañas heladas y apenas existen árboles sin hojas. 


\section{Análisis comparativo}

Cuerpos humanos. Los cuerpos se han pintado en escala ligeramente menor a la escala humana real; la figura más grande alcanza los 1.45 metros; proporcionalmente esta altura corresponde a 7.5 de su propia cabeza. Es notoria la exageración que el artista aplicó en algunas partes del cuerpo, por ejemplo, en las extremidades superiores, las cuales se encuentran muchas veces muy separadas del tronco y en posiciones forzadas, además de presentar musculatura muy desarrollada. Las manos y los dedos (índice y medio separados del anular y meñique), así como la orientación de los pies, que forman un ángulo recto mientras se mantiene la postura erguida del cuerpo, corresponden a la posición típica de las esculturas neoclásicas.

Existe un patrón en la distribución de colores, que se debe principalmente a la presencia de grandes extensiones de cielo y vegetación en los paisajes que sirven de fondo; así, de manera vertical de arriba hacia abajo predominan los colores fríos (azules) que a veces cambian hacia cálidos (si la representación es primavera o verano), o presentan un corte abrupto con perfiles verdes (árboles) y, finalmente, concluyen en colores cálidos de la tierra. Sea cual fuera el caso, la figura principal destaca por los colores pálidos del cuerpo.

Indumentaria. Todos los personajes muestran una vestimenta típica de los tiempos grecorromanos, es decir, durante el periodo del clasicismo. Destaca el uso de la prenda denominada 'chitón' con flecos, acompañada en el caso del invierno de una gran pieza conocida como 'himatión'. Entre los colores empleados, destaca el azul intenso, también presente en la carpintería del mismo atrio; sin embargo, también están presentes tonos grises, el pardo claro y el color dorado. El calzado es muy similar a los llamados 'krépis', es decir, piezas únicas que cubrían la planta y que poseían agujeros para pasar correas que se enredaban en la pantorrilla, además de una lengüeta que cubría parte del empeine. Una vez más el caso del invierno es una excepción: al parecer utiliza un calzado llamado 'emdromis', una especie de bota para travesías. Algunos elementos pueden considerarse como accesorios complementarios: guirnaldas y coronas de flores, además de collares y pulseras. Cabe notar entonces que las vestimentas, aunque por sus características no marcan las formas humanas, y más bien destacan las geométricas, y los pliegues que resaltan las sombras y brillos, también dejan ver grandes áreas de piel, principalmente de los brazos y el torso, lo cual da a la imagen un aspecto escultórico debido al volumen de la musculatura y la posición de las extremidades.

Paisaje. Todas las representaciones presentan imágenes de árboles y vegetación que acompañan, y sirven de fondo y contraste a las figuras humanas. Son en particular importantes, pues no solo aportan un fondo tonal que hace resaltar la claridad de los cuerpos principales ubicados en primer plano, sino también porque permiten reconocer algunas especies de árboles propios de la zona, como el huarango y el molle, y algunos arbustos propios de los valles costeños, como la caña brava y la totora; en el caso de la primavera y el verano, aparece además un tipo de palma y un tipo de ponciana respectivamente. También se observa que, aunque parecieran ser montañas las formaciones geológicas del fondo, en todo caso montañas azuladas que podrían indicar los Alpes europeos, debido a la escala parecen ser cerros costeños, pues además están desprovistos de vegetación, lo que coincide con el panorama local.

Castillos. Los dos entrepaños menores son el soporte de dos imágenes referidas a paisajes en los que destacan y ocupan gran parte del área pintada castillos de evidente modelo europeo. La primera se ubica entre las imágenes de la primavera y el verano, y la segunda entre otoño e invierno. La primera (Figura 21) representa un elevado edificio de tres niveles sobre el cual existe incluso un mirador de tres niveles y una linterna, lo que la hace muy elevada. Este edificio es muy ligero debido a la repetición del uso de columnas y arcos de medio punto, así como el uso constante de cupulines pintados de azul. En la primera planta, sin embargo, el trazo de un arco ojival delata su relación
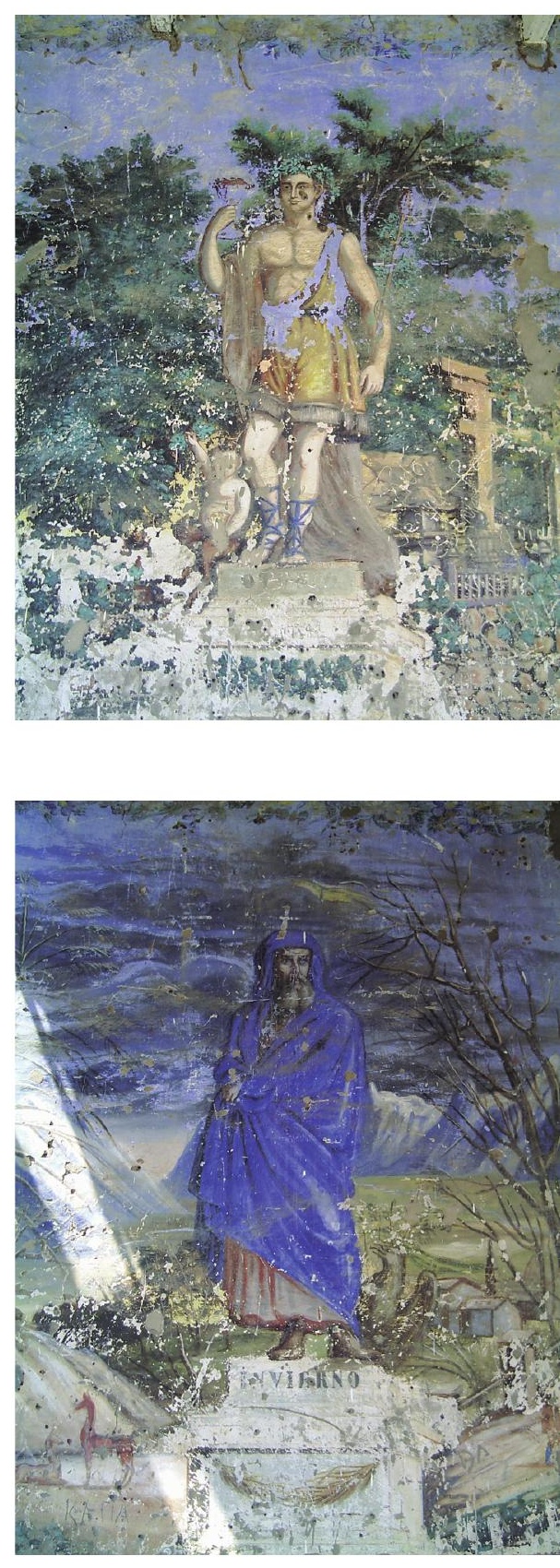

Figura 19. El otoño

Fuente: Archivo fotográfico Carlos Alvino, 2006.

Figura 20. El invierno

Fuente: Archivo fotográfico Carlos Alvino, 2006. 

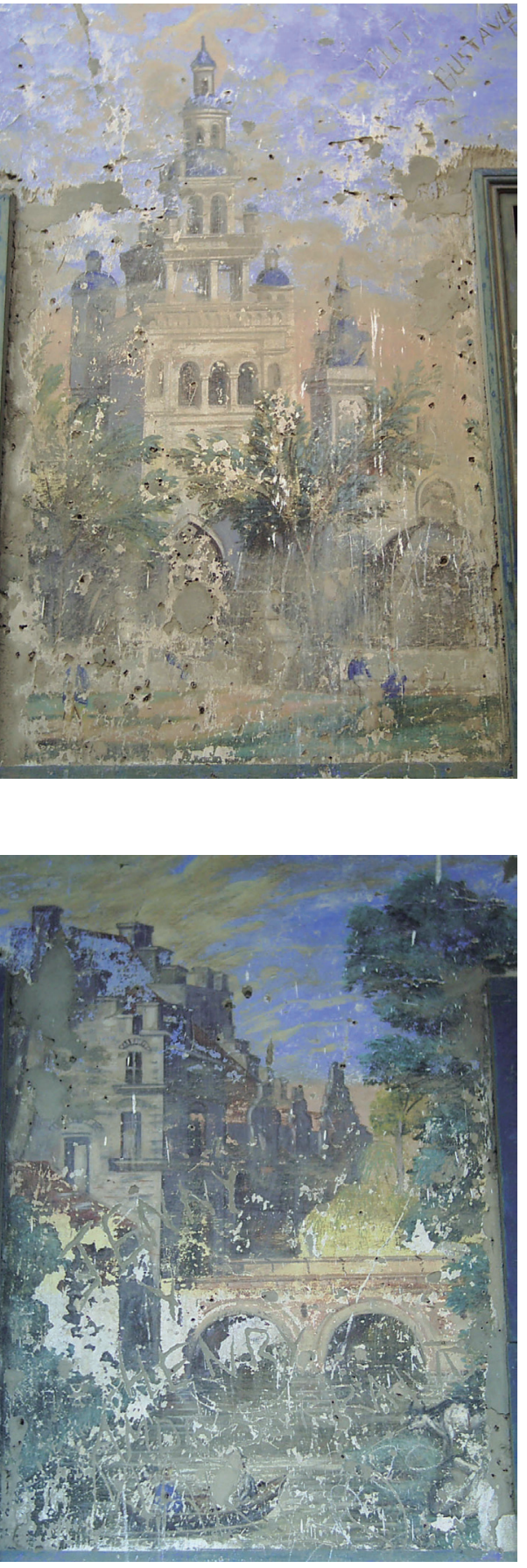

Figura 21. El castillo gótico - románico

Fuente: Archivo fotográfico Carlos Alvino, 2006.

Figura 22. El castillo y el puente

Fuente: Archivo fotográfico Carlos Alvino, 2006. con el gótico. Muy cerca a este edificio existe otro mucho menor que parece ser un mausoleo romano debido a su techumbre de cúpula; otro edificio, una torre apuntada, completa el conjunto arquitectónico que al parecer es irreal. En primer plano resulta interesante la existencia de un río en el cual algunos personajes vestidos de azul parecen pescar o pasear simplemente.

El segundo paisaje (Figura 22) es un edificio mucho más masivo, inmediato a un río y al cual se accede por un puente de piedra con doble arco de medio punto. El edificio al parecer cuenta con cinco niveles, y posee terrazas con almenas y techos inclinados. Igualmente existen personajes ataviados de manera romántica con traje azul, que se encuentran en paso en bote sobre el río, mientras en los alrededores existe mucho follaje y árboles muy altos.

Amorcillos. Una imagen reiterativa es la de varios amorcillos que representan a Cupido, dios del amor romano (representado por un niño con alas). Las imágenes los representan volando en diferentes posiciones y con objetos propios de la personalidad de estos personajes alados; por ejemplo, el existente entre la primavera y el primer castillo posee dos cornucopias, símbolos de riqueza, y con ellas al parecer está distribuyendo al aire monedas. Otro, entre un castillo y la imagen del invierno, se encuentra de espaldas en actitud de haber lanzado una flecha con su arco. Es importante destacar los presentes en el paño central de la pared, arriba del dintel de la puerta principal (Figura 23), pues ellos sostienen un escudo, el cual posee varias escotaduras que recuerdan al escudo nacional, pero este solamente contiene en su interior el número 1862, al parecer la fecha de realización de la obra.

Personajes secundarios. A pesar de las dificultades por el estado de conservación de las pinturas en su parte inferior, se logra identificar al menos tres personajes adyacentes o secundarios a las imágenes humanas representativas de las cuatro estaciones, con las cuales poseen una asociación directa. El primer caso, asociado a la primavera, es un niño desnudo cubierto de flores que parecen envolverlo y elevarlo. En su mano derecha parece sostener una antorcha dorada (quizás asociada a Deméter) y en la izquierda un haz de ramas doradas. Un segundo caso lo representa la imagen de un sátiro, más probablemente el dios Pan, pues la parte inferior del cuerpo es la de una cabra, aunque lamentablemente la pintura se encuentra deteriorada; no obstante, se puede ver que tiene la mano derecha en alto y con la izquierda sostiene una copa de oro, lo que ratifica su identidad, pues tal objeto se asocia a Dionisio, dios del vino. Pan es un personaje alegre en busca de placeres; en el caso de estas pinturas se asocia al otoño, probablemente como época de cosecha del vino o de festividades locales. El tercer caso representa la imagen de un águila o ave rapaz de oscuro plumaje que se esconde tras la imagen humana que representa al invierno.

Edificios de fondo. Acompañando a las representaciones de las estaciones (a excepción del verano) se presentan como parte integrante del paisaje algunos edificios que se ven lejanos o en segundo plano. A la derecha de la primavera aparece probablemente el edificio correspondiente a una abadía, donde destaca una torre con cúpula de media naranja con linterna. Alrededor de esta torre existen varios volúmenes con techos a doble agua, probablemente de tejas, pues presentan color rojo intenso. En el correspondiente a otoño destaca el mencionado anteriormente arco oriental o chino, que probablemente simboliza el rasgo exótico de un paseo, quizás en un parque de exposición, de moda en el siglo XIX. Finalmente, detrás de las ramas secas de la composición relativa a invierno aparece un grupo de casas muy sencillas y una torre apuntada que se emplaza en una estepa fría y rala.

Personajes en miniatura y en primer plano. Es interesante observar las representaciones secundarias existentes en los primeros planos de cada una de las pinturas de las cuatro estaciones. Aunque se encuentran en dicho lugar importante, su escala responde a una división jerárquica, pues presentan un tamaño diminuto en compara- 

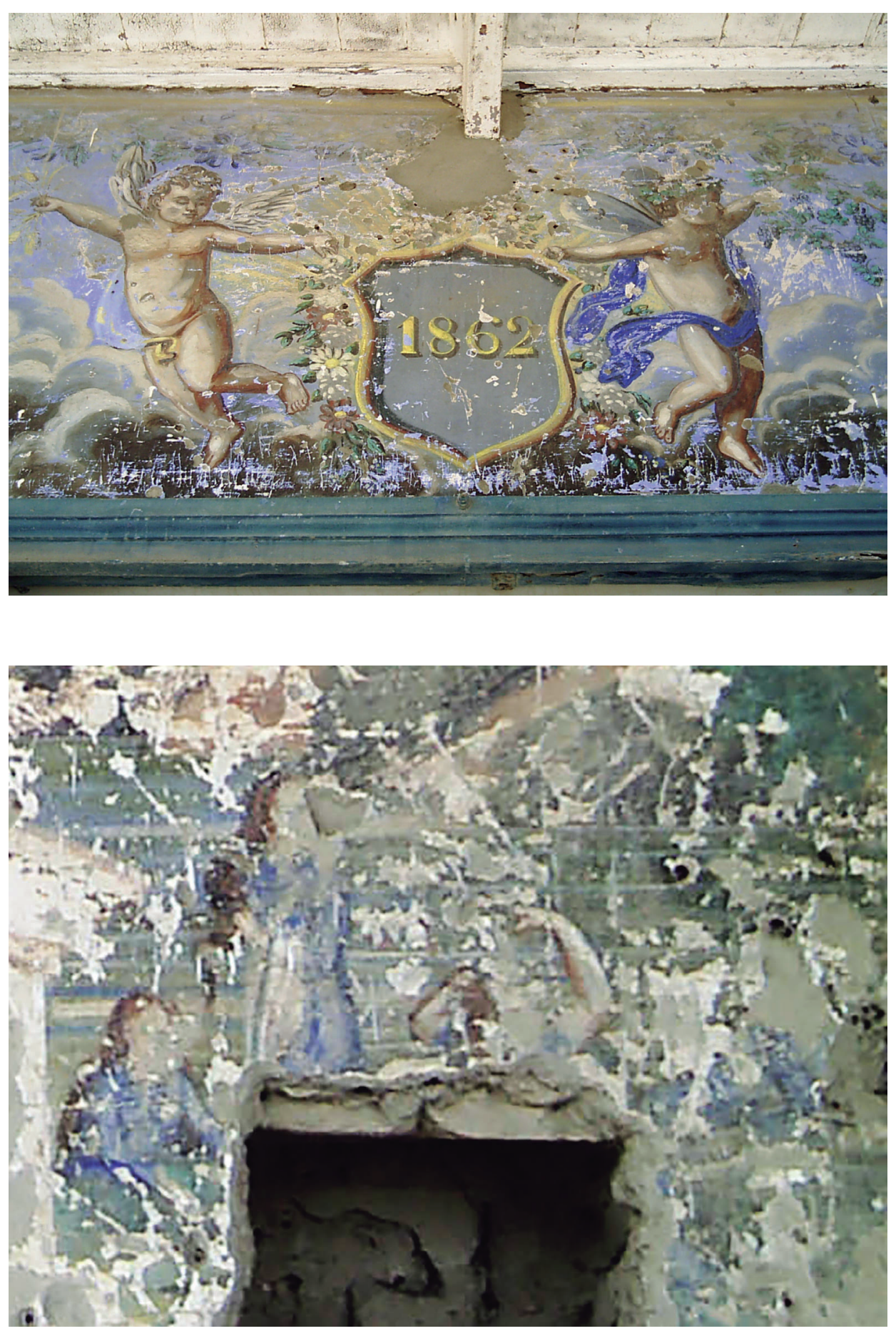

ción con la imagen principal; se ubican en la parte inferior e incluyen incluso espacios en los que existen grupos sin que esto perturbe la visibilidad de la imagen central de cada estación. A diferencia de las logradas imágenes de las estaciones, estos grupos se ven resueltos de manera sencilla y rápida, casi a pincelazos lineales, y no pueden identificarse los rasgos de los rostros, pero sí las vestimentas y algunas posiciones. Por su disposición y entorno presentan un estilo romántico y paisajista.
Figura 23. Amorcillos sosteniendo un escudo con escotaduras y fecha conmemorativa. Se ubica sobre el dintel de la puerta central

Fuente: Archivo fotográfico Carlos Alvino, 2006.

Figura 24. Conjunto de mujeres bañándose en un río (desaparecida actualmente)

Fuente: Archivo fotográfico Carlos Alvino, 2006. 
Lagunas y cisnes. Acompañan a la representación de la primavera. Se trata de un tranquilo lago rodeado de maguey y rocas, alrededor del cual se ubican personas que observan a las aves nadando.

Baño campestre (Figura 24). Se encuentra en la parte inferior derecha de la representación del verano. Aunque se halla muy destruida, es probable que se trate de un grupo de cuatro mujeres jóvenes vestidas todas con traje de baño antiguo azul, que toman aguas en un río. Todas observan una posición distinta mientras lavan su largo cabello o conversan.

Pastor y llamas. Acompañan a la figura que representa al invierno. Es muy interesante, pues por primera vez se presenta una imagen completamente asociada a los Andes. Se trata de un poblador local que parece ser un pastor o llamero, pues se encuentra acompañado de dos llamas muy bien delineadas en actitud de descanso (una parada y la otra echada). El llamero carga un bulto a sus espaldas y ostenta vestimenta claramente andina; el entorno es un camino o una trocha del campo. Es también destacable que en el otro extremo del camino son visibles dos personas, posiblemente caballeros criollos, que se encuentran caminando sin preocupación laboral y están por dar encuentro al llamero.

\section{Las cuatro estaciones en el arte}

El tema de las cuatro estaciones ha sido desarrollado en diferentes momentos, y está asociado a diversos estilos y géneros artísticos. Interesa acercarse a las representaciones grecorromanas existentes en el mural de Caqui, las que además parecen poseer ciertas características escultóricas; es decir, podrían haber sido tomadas de modelos escultóricos reales, estampas o pinturas que poseen esos rasgos formales. Por las particularidades que presentan las imágenes del atrio, es probable que pudieran haber sido tomadas de los modelos escultóricos neoclásicos en plena vigencia desde fines del siglo XVIII en Europa y cuya influencia perduró incluso hasta el siglo XIX. En la época en que se realizó el mural, las referencias de pinturas grecorromanas eran de difícil acceso, como lo afirma Pijoan: "Mientras en toda Europa, y hasta en América, la arquitectura aceptaba decididamente las formas de un arte antiguo [...]. En pintura esa "neoclasización" iba a resultar casi imposible, ya que era poquísimo entonces, lo que se sabía de la pintura romana antigua habían revelado las incipientes excavaciones en Pompeya" (1964, p. 90). De manera comparativa se han recopilado algunos ejemplos escultóricos que guardan cierta semejanza formal y estilística con el mural de la Hacienda Caqui.

Existen representaciones de las cuatro estaciones en esculturas individuales, en diferentes ciudades de Latinoamérica, por ejemplo, en la ciudad de Montevideo, donde fueron importados de Italia durante la primera mitad del siglo XIX. En todos los casos se distingue el tipo social correspondiente (personajes del mundo grecorromano), cuya vestimenta y ciertos elementos iconográficos son similares a los presentes en las pinturas existentes en Caqui; particularmente es similar la representación del invierno, un hombre barbado y viejo que se abriga con una larga toga.

Son también similares algunas posiciones corporales; sin embargo, las proporciones son diferentes, pues los personajes parecen más pasivos y reposados, con los brazos más laxos, en las esculturas de Montevideo. Tampoco existen los calzados identificados en las pinturas y evidentemente las estatuas son individuales, sin personajes adyacentes. Uno de los conjuntos de cuatro estaciones más tempranamente registrados durante el siglo XIX se encuentra en Las Palmas, Gran Canaria. Fechado hacia 1815, sus esculturas son representaciones neoclásicas de esculturas en mármol, y presentan una composición alargada y de corte grecorromano. En Lima también fueron ubicadas en espacios públicos estatuas referidas a las cuatro estaciones, inicialmente en la Plaza Mayor, actualmente distribuidas a lo largo del Paseo Colón. En Caqui, aunque conservan algunos lineamientos temporales, principalmente la que representa a la primavera, en las otras se han cambiado el atuendo y algunos elementos iconográficos, lo que las hace parecer representaciones de diversos tiempos. 


\section{Conclusiones}

Existen en la localidad de Caqui, provincia de Huaral, Lima, Perú, obras artísticas que evidencian la diversidad de mentalidades e ideologías que existieron en el pasado, y que son representativas de la costa central andina; estas obras son sin duda parte importante del patrimonio artístico del hombre costeño y su singularidad las hace distinguibles entre muchas otras. El edificio La Bandurria representa un tipo de arquitectura que expresa la interrelación entre la sociedad Chancay y el Tawantinsuyu; es un edificio que respalda el poder y la religiosidad que existía en esta parte de la costa. Los rasgos estilísticos escalonados son únicos en el valle y lo relacionan con otras edificaciones contemporáneas donde el signo escalonado es una forma paradigmática dentro de la estructura cultural vigente. Los grafitis, en algunos lugares del mismo edificio, responden asimismo a una práctica estética costeña existente hace siglos y, por lo tanto, a una forma de resistencia ideológica asociada a las huacas locales, sintetizadas y ubicadas por esta razón de manera secundaria.

Las representaciones pictóricas existentes aún en la casa hacienda Caqui son evidencia de una preocupación de parte de los sectores sociales terratenientes por mantener un nivel cultural y artístico en un medio evidentemente rústico, campestre y alejado de la ciudad. Las temáticas y los rasgos existentes en las obras pictóricas revelan una filiación y contacto con los gustos académicos más cosmopolitas de entonces, pero también revelan una profunda devoción religiosa. La casa hacienda fue la expresión del poder que una clase social tuvo sobre el territorio; las pinturas murales subrayan este principio, pues emplean un lenguaje hasta cierto punto ajeno al campesinado y entendible solo para los asociados a la clase dominante. La casa hacienda de Caqui posee en diversas partes de su edificación numerosas pinturas que indican una preocupación por transmitir el poderío y alcance económico que se extiende incluso hasta otros países (prueba de eso son las imágenes marítimas, de castillos y de banderas de países atlánticos). Los murales son imágenes introducidas de otros contextos, que aparecen ante la vista del poblador como el rango de alcance cultural y social de la 'hacienda' misma.

Las pinturas murales del atrio se encuentran asociadas al romanticismo en cuanto a los paisajes e imágenes que recrean el tema principal, un tema mitológico grecorromano que se rescata durante el neoclasicismo. Sin embargo, este mismo tema también se encuentra directamente asociado al entorno agrícola y a las finalidades económicas de la misma hacienda, por cuanto existe una intencionalidad en su ejecución.

Técnicamente, las pinturas han sido efectuadas dando privilegio a la figura humana mediante trazos largos y continuos de pincel, los cuales al ser aplicados por la técnica de pintura al fresco (técnica que tiene que ser ejecutada rápidamente) demuestran una seguridad y habilidad en el artista digna de admirarse.

El dibujo para evidenciar la estructura compositiva de una obra es muy importante en la expresión del neoclásico, y este lo vincula precisamente con la escultura: "Como en pintura, el punto de partida de la escultura neoclásica es el dibujo (...) el dibujo neoclásico vas asociado más bien, a un análisis de las posibilidades técnicas y estéticas de la escultura." (Reyero \& Freixa, 1995, p. 41) Algunos desprendimientos y transparencias de capas pictóricas dejan ver que los fondos fueron pintados inicialmente de arriba hacia abajo con grandes trazos, siguiendo a estos las zonas paisajísticas; aunque este modo de lograr las pinturas es casi uniforme en toda la casa hacienda, es posible encontrar ciertas variantes en algunas pinturas de la capilla, lo que permitiría pensar en la participación de más de un artista.

Finalmente, el colapso socioeconómico del sistema de las haciendas, ya en el siglo XX, ha provocado no solamente el abandono de las casas haciendas, las cuales son monumentos cuya tipología arquitectónica es única, sino que también conllevó al olvido de muchas de las expresiones artísticas que se asociaban a ellas y que actualmente se encuentran en un acelerado proceso de destrucción. 
devenir Vol. 3, N6, JULIO-DICIEMBRE 2016, PP. 143-162 - EstudIOS I ISSN 2312-7570

UNIVERSIDAD NACIONAL DE INGENIERÍ, LIMA

\section{Agradecimientos}

A los alumnos del curso de Conservación del Patrimonio Edificado de la Universidad Ricardo Palma (grupo 03, 2016-1) por el apoyo en campo, y a Nelly Giannina López Céspedes por la revisión del texto.

\section{Referencias}

Alvino, J. (2009). Expresiones rupestres prehispánicas en el valle de Chancay. El petrograbado de Caqui [Manuscrito de la ponencia presentada al XVI Congreso del Hombre y la Cultura Andina Julio César Tello Rojas]. Facultad de Ciencias Sociales, Universidad Nacional Mayor de San Marcos, Lima, Perú.

Alvino, J. (2016). Arte mural en la hacienda de Caqui, valle de Chancay [Monografía sin publicar]. Facultad de Letras y Ciencias Humanas, Universidad Nacional Mayor de San Marcos, Lima, Perú.

De Lavalle, J.A. \& Lang, W. (Eds.). (1982). Arte y Tesoros del Perú. Culturas Precolombinas. Chancay. Lima. Perú: Banco de Crédito del Perú.

Bernales, J. et al. (1991). Escultura en el Perú. Lima, Perú: Banco de Crédito del Perú.

Carrión, R. (1959). La religión en el antiguo Perú. Lima, Perú.

Garayar, C. et al. (1997). La hacienda en el Perú. Historia y leyenda. Lima, Perú: Banco Latino - PEISA.

Guzmán, M. (2016). Arquitectura chancay. Espacios rituales del tiempo sagrado. Lima, Perú: Universidad Ricardo Palma.

Horkheimer, H. (1965). Identificación y bibliografía de importantes sitios prehispánicos del Perú. Arqueológicas (Revista del Museo Nacional de Antropología y Arqueología), 8, 40-51.

Instituto Geográfico Nacional (1971). Carta Nacional, 24-i. Lima, Perú.

Joly, L. (1982). El signo y la forma. Lima, Perú: Universidad de Lima.

Keith, R. et al. (1970). La hacienda, la comunidad y el campesino en el Perú. Lima, Perú: Instituto de Estudios Peruanos - Moncloa Campodónico.

Martínez, A. (2006). "A pesar del Gobierno". Españoles en el Perú, 1879-1939. Madrid, España: Consejo Superior de Investigaciones Científicas.

Ministerio de Educación (2007). Plan del Bicentenario. Perú hacia el 2021. Serie 1. Agro y tecnología en la historia del Perú. Lima, Perú: Autor.

Pijoán, J. (1964). Historia del arte. Madrid, España: Salvat.

Ruíz, A. (1983). Arte andino en Rapaz. Boletín de Lima, 28(año 5), 43-52. 